Primljen / Received: 26.12.2013. Ispravljen / Corrected: 19.2.2014.

Prihvaćen / Accepted: 20.4.2014. Dostupno online / Available online: 10.5.2014.

\section{Analysis of flange impact on critical patch load of thin-walled I-girders}

Authors:

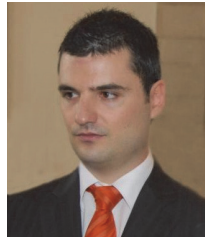

Milivoje Rogač, MSc. CE University of Monte Negro Faculty of Civil Engineering in Podgorica milivojer@ac.me

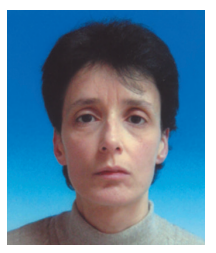

Assist.Prof. Olga Mijušković, PhD. CE University of Monte Negro Faculty of Civil Engineering in Podgorica olja_64@yahoo.com

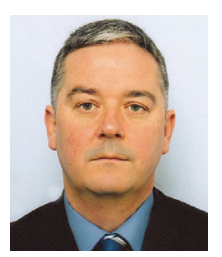

Prof. Duško Lučić, PhD. CE

University of Monte Negroe

Faculty of Civil Engineering in Podgorica dlucic@ac.me

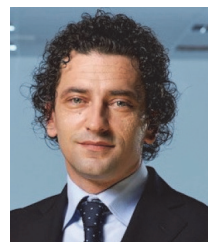

Assist.Prof. Srda Aleksić, PhD. CE University of Monte Negro

Faculty of Civil Engineering in Podgorica asrdja@ac.me

\section{Milivoje Rogač, Olga Mijušković, Duško Lučić, Srda Aleksić}

Preliminary note

\section{Analysis of flange impact on critical patch load of thin-walled I-girders}

A numerical analysis of the flange impact on the critical load level of thin-walled I-girders subjected to patch load with special emphasis on the influence of shear stress in the zone of transverse stiffeners and shear stress at the flange-web junction on the girders response, is presented in this paper. The analysis is done by forming a $3 \mathrm{D}$ model in Abaqus software based on the finite element method, through variation of flange to web thickness ratio. $2 \mathrm{D}$ numerical models of girders web as isolated plate are also created. Matching of the 2D numerical results with results of existing analytical model, is the real basis for the expected accuracy of the $3 \mathrm{D}$ model.

Key words:

Elastic stability, thin-walled I-girders, patch load, numerical analysis, shear stress

Prethodno priopćenje

Milivoje Rogač, Olga Mijušković, Duško Lučić, Srda Aleksić

\section{Analiza utjecaja pojasnica na kritično koncentrirano opterećenje tankostijenog I-nosača}

U radu je prikazana numerička analiza utjecaja pojasnica na razinu kritičnog opterećenja tankostijenog I-nosača opterećenog koncentriranim opterećenjem. Analiza je provedena formiranjem 3D modela u programskom paketu Abaqus na temelju metode konačnih elemenata, varirajući odnos debljine pojasnica prema debljini hrpta. Podudaranje rezultata $2 \mathrm{D}$ numeričkih modela hrpta nosača kao izdvojene ploče s rezultatima postojećeg analitičkog modela predstavlja realnu osnovu na kojoj se temelji očekivana točnost 3D modela.

Ključne riječi:

elastična stabilnost, tankostijeni I-nosači, kritično opterećenje, numerička analiza, posmična naprezanja

Vorherige Mitteilung

Milivoje Rogač, Olga Mijušković, Duško Lučić, Srda Aleksić

\section{Analyse des Einflusses von Flanschen auf die kritische Punktlast von} dünnwandigen I-Profilen

In der vorliegenden Arbeit wird eine numerische Analyse des Einflusses von Flanschen auf das Niveau der kritischen Belastung von dünnwandigen I-Profilen unter Punktlasten dargestellt. Die Analyse ist auf einem im Softwarepaket Abaqus durch finite Elemente erstellen 3D Modell beruhend, durchgeführt worden, indem das Verhältnis von Flanschenund Stegstärke variiert wurde. Übereinstimmende Ergebnisse 2D-numerischer Modelle der Flanschen als einzelner Platten und des analytischen Modells werden als angemessene Grundlage für die erwartete Genauigkeit des 3D-Modells angenommen.

Schlüsselwörter:

elastische Stabilität, dünnwandiger I-Profil, kritische Last, Numerische Analyse, Schubspannungen 


\section{Introduction}

The patch load is the load that acts locally over the small length/surface of a structural element. The stability of thinwalled I-girders subjected to the patch load acting in the web plane of the girder is a problem of particular interest (Figure 1).

The solution to this problem is theoretically developed using two different approaches. The first one involves the critical buckling load based on the theory of elastic stability, while the second approach concerns a mechanical model based on the first theorem of limit analysis, for a previously adopted failure mechanism. The relevant European standard that deals with the capacity calculation for plated girders subjected to concentrated loads EN1993-1-5 [1] is based on a combination of the aforementioned approaches. This research deals with the problem of elastic stability of I-girders subjected to patch load.
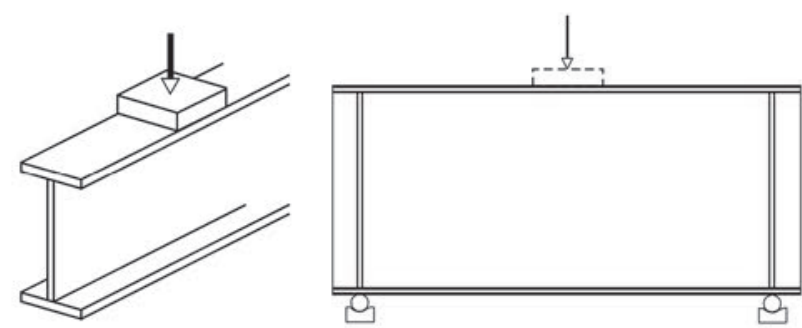

Figure 1. Thin-walled I-girder subjected to patch load

In order to define analytical solutions to the problem, the I-girder web is usually treated as an isolated plate. Zones of vertical stiffeners (Figure 1) are modelled as simply supported edges of the plate, while longitudinal edges, depending on the thickness of the flanges, are modelled as simply supported edges (thinner flanges) or clamped edges (thicker flanges). In literature, it is sometimes stated that the approach to solving critical force according to the theory of elastic stability of plates can not describe the real behaviour of the girder (Figure 1). The reason for these statements is the fact that during the analysis of elastic stability of plates the external load is usually approximated with loads uniformly distributed along the edges of the plate, i.e. an approximate function of stresses in the plate is adopted. This approximation significantly affects the intensity of critical load. The importance of introducing the exact function of stress distribution in the stability analysis of rectangular plates is confirmed in the doctoral thesis [2].

Besides the exact stress function in the girder web, the introduction of flange in the stability analysis of I-girder through a series of effects (elastic restraint of edges on the web-flange junctions; bending, axial and torsional stiffness of the flange; load propagation through the flange) increases the value of the buckling coefficient. The aforementioned thesis has been studied by numerous authors [3-6] and this primarily through numerical analyses based on the finite element method, so as to take into account the complexity of the problem and a large number of parameters that affect the critical load intensity of thin-walled I-girders. Lagerqvist and Johansson [3] have studied the influence of flanges on the elastic stability of I-girders, as well as the impact of the loading length on critical load. Based on the aforementioned numerical study, an expression for calculating the buckling coefficient of thin-walled I-girders under the patch loading is suggested. A simplified version of the expression is an integral part of the Eurocode 3 (EN 1993-1-5:2006, Figure 6.1) [1].

The problem is still topical, despite the large number of extensive researches that have been conducted so far. A numerical analysis of the impact of flanges on the critical load intensity of thin-walled I-girders subjected to patch load, with a special emphasis on the influence of shear stresses in the zone of transverse stiffeners, and shear stresses at the flange-web junctions on the girders response, is presented in this paper. The analysis is conducted by forming a 3D model based on the finite element method (Figure 4) using the Abaqus software [7], through variations of the flange to web thickness ratios. In order to adequately select the finite element type and mesh density for the 3D model, 2D numerical models of plates (Figure 2), with different boundary conditions, are also created. The consistence of $2 \mathrm{D}$ numerical and existing analytical [8] results is the real basis for the expected accuracy of the $3 \mathrm{D}$ numerical analysis.

\section{Numerical analysis}

\subsection{General parameters of numerical models}

All numerical tests are conducted according to the "eigenvalue buckling" analysis procedure using the Abaqus/Standard processor [7], Minimum critical forces, i.e. the first buckling modes, are calculated. In the Abaqus software, buckling modes are generalized vectors rather than real deflections at critical load, and so the maximum magnitude of all deflections presented in sections 2.2 and 2.3 amounts to 1.0.

The patch load is modelled as a series of concentrated forces distributed in finite-element nodes over the length /. The adopted type of loading led to dense mesh of finite elements (5x5 mm). High density of mesh did not significantly affect the calculation speed in both cases (2D and 3D models), and so an additional convergence analysis was not performed. A fournoded first-order $\$ 4$ shell element found in Abaqus libraries [7] was employed for the simulation. The element has four integration points and six degrees of freedom per node. Since the first-order $\mathbf{5} 4$ element uses a linear interpolation along its edges, the local uniform edge loading (patch loading) gives equivalent point loads in the ratio 1:2:1 at the corner, midside, and corner nodes, respectively. At the beginning of the analysis, several numerical tests with a second-order S8R5 shell element were conducted. Negligible deviation of results compared to models with the $\$ 4$ finite element, and 
more expensive calculation with the S8R5 element, are the reasons why the $\mathbf{5 4}$ shell finite element was selected for further analysis.

The following mechanical properties of material were adopted: $E=10000 \mathrm{kN} / \mathrm{cm}^{2}-$ Young's modulus; $v=0.3$ - Poisson's ratio.

\subsection{Web as isolated plate}

The critical load $\sigma_{c r}$ was calculated for square plates as follows: $a$ $\mathrm{x} b=700 \times 700 \mathrm{~mm}$ (plate dimensions), $t_{w}=10 \mathrm{~mm}$ and $t_{w}=5 \mathrm{~mm}$ (plate thickness), SSSS and CSCS (boundary conditions), $I=70 \mathrm{~mm}$

Load type 1

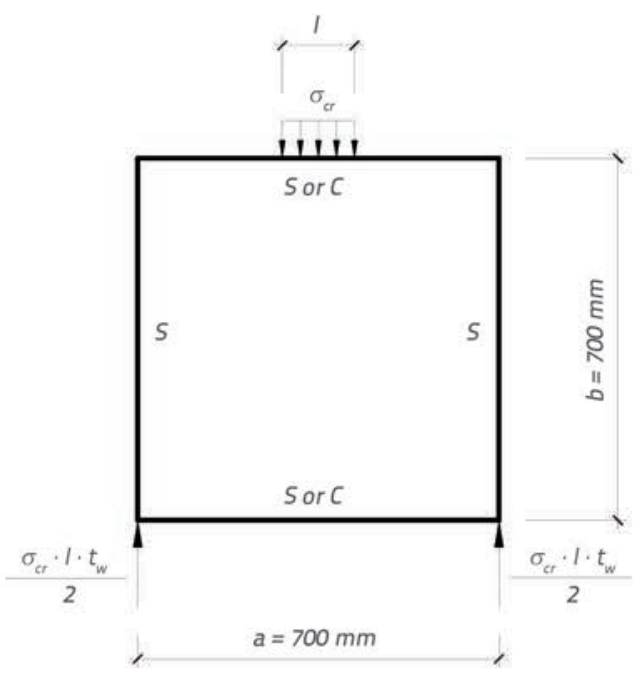

and $/=210 \mathrm{~mm}$ (load length), Figure 2 . Accordingly, the analysed ratio of plate dimensions amounted to $\varnothing=a / b=1$, and analysed ratios of load length to plate spans were $\gamma=/ / a=0,1$ and 0,3. For simply supported (S) and clamped (C) edges of plates nodes, the displacement perpendicular to the plate plane was restrained, while in the case of the $C$ boundary condition nodes the rotation about the supporting direction was also restrained. The influence of shear stresses in the zones of transverse stiffeners on the critical load intensity was analysed through various load types. The type 1 load represents a realistic web simulation for the majority of experimentally tested short girders, where the Load type 2

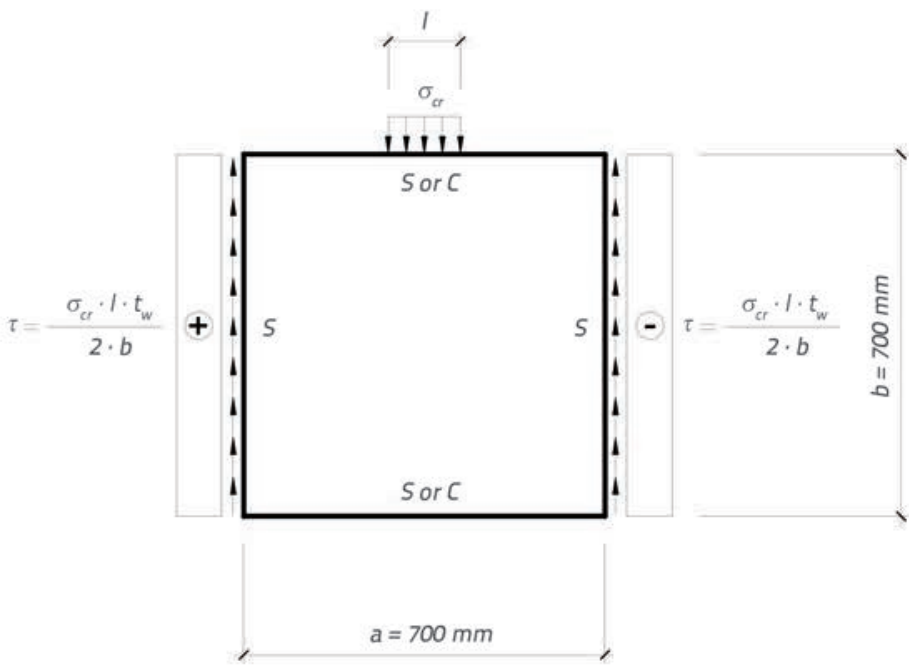

Figure 2. I-girder web as isolated plate

Table 1. Results of numerical analysis - web as isolated plate

\begin{tabular}{|c|c|c|c|c|c|c|c|c|c|}
\hline Load type & $\begin{array}{l}\text { Boundary } \\
\text { conditions }\end{array}$ & $\gamma$ & $\begin{array}{c}t_{w} \\
{[\mathrm{~mm}]}\end{array}$ & $\begin{array}{c}\mathrm{F}_{\mathrm{cr}} \\
{[\mathrm{kN}]}\end{array}$ & $\begin{array}{c}\text { Relation of loads } \\
\text { Type } 2 \text { / Type } 1 \\
\text { [\%] }\end{array}$ & $\begin{array}{c}\sigma_{\mathrm{cr}} \\
{\left[\mathrm{kN} / \mathrm{cm}^{2}\right]}\end{array}$ & $\mathrm{k}$ & $\begin{array}{c}\text { Analytic } \\
\text { solution } \\
\text { k [8] }\end{array}$ & $\begin{array}{c}\text { Deviation } \\
{[\%]}\end{array}$ \\
\hline \multirow{8}{*}{ Type 1} & SSSS & 0,1 & 10 & 379,830 & & 52,26 & 29,42 & \multirow{2}{*}{29,63} & 0,72 \\
\hline & SSSS & 0,1 & 5 & 47,549 & & 13,59 & 29,46 & & 0,57 \\
\hline & SSSS & 0,3 & 10 & 100,150 & & 19,05 & 10,33 & \multirow{2}{*}{10,41} & 0,76 \\
\hline & SSSS & 0,3 & 5 & 50,088 & & 4,77 & 10,34 & & 0,63 \\
\hline & CSCS & 0,1 & 10 & 737,040 & & 105,29 & 57,08 & \multirow{2}{*}{57,41} & 0,57 \\
\hline & CSCS & 0,1 & 5 & 92,437 & & 26,41 & 57,27 & & 0,24 \\
\hline & CSCS & 0,3 & 10 & 767,740 & & 36,56 & 19,82 & \multirow{2}{*}{19,92} & 0,50 \\
\hline & CSCS & 0,3 & 5 & 96,248 & & 9,17 & 19,88 & & 0,21 \\
\hline \multirow{8}{*}{ Type 2} & SSSS & 0,1 & 10 & 424,490 & 11,76 & 60,64 & 32,88 & & \\
\hline & SSSS & 0,1 & 5 & 53,161 & 11,80 & 15,19 & 32,94 & & \\
\hline & SSSS & 0,3 & 10 & 453,290 & 13,28 & 21,59 & 11,70 & & \\
\hline & SSSS & 0,3 & 5 & 56,760 & 13,32 & 5,41 & 11,72 & & \\
\hline & CSCS & 0,1 & 10 & 895,890 & 21,55 & 127,98 & 69,39 & & \\
\hline & CSCS & 0,1 & 5 & 112,490 & 21,69 & 32,14 & 39,70 & & \\
\hline & CSCS & 0,3 & 10 & 949,520 & 23,68 & 45,22 & 24,51 & & \\
\hline & CSCS & 0,3 & 5 & 119,130 & 23,77 & 11,35 & 24,60 & & \\
\hline
\end{tabular}


Table 2. First buckling modes of plate, $\mathrm{t}_{\mathrm{w}}=10 \mathrm{~mm}$

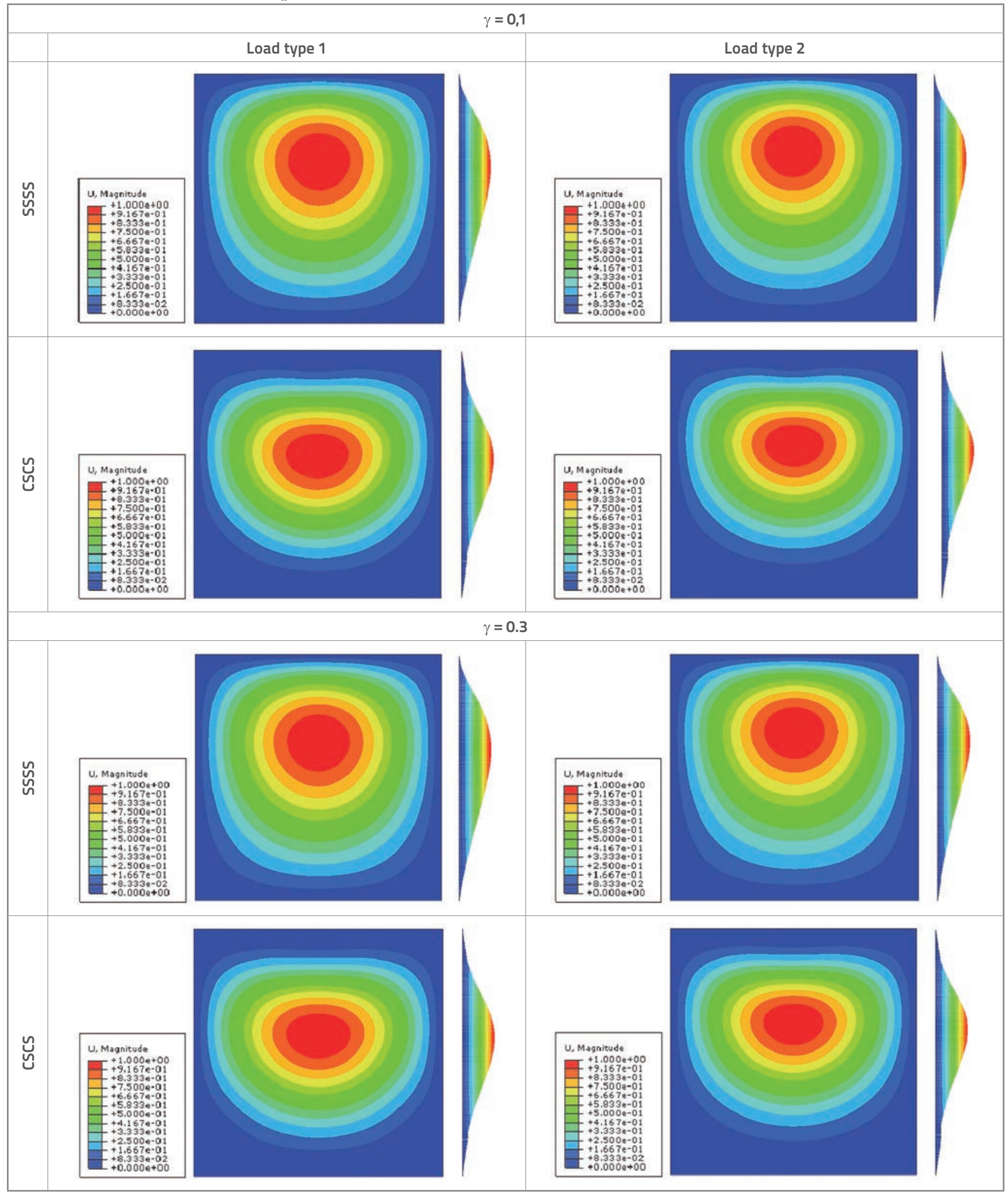

patch load is equilibrated with supporting reactions (Figure 2 - left). However, we have much longer girders in practice, where the web stability control is conducted on an isolated part of the web between transverse stiffeners. In the zone of transverse stiffeners, shear stresses occur as a result of transverse cross-sectional forces. According to the theory of 
thin-walled sections, the distribution of shear along the web height is parabolic. However, it has been proven in literature [9] that the parabolic distribution of shear can be accurately approximated with uniform shear stresses along the web height $(\tau)$ in case of critical buckling load calculation (Figure 2, type 2 load).

The critical buckling stress was calculated according to the formula (1) based on the critical force $F_{c r^{\prime}}$ which in turn was calculated using the Abaqus software, while the buckling coefficient $k$ from Table 1 was determined according to the formula (3).

$\sigma_{c r}=\frac{F_{c r}}{t_{w} \cdot l}$ - critical buckling stress

$\sigma_{c r}=k \cdot \frac{\pi^{2} \cdot E}{12 \cdot\left(1-v^{2}\right)} \cdot\left(\frac{t_{w}}{a}\right)^{2}-$ critical buckling stress

$k=\sigma_{c r} / \frac{\pi^{2} \cdot E}{12 \cdot\left(1-v^{2}\right)} \cdot\left(\frac{t_{w}}{a}\right)^{2}$ - buckling coefficient

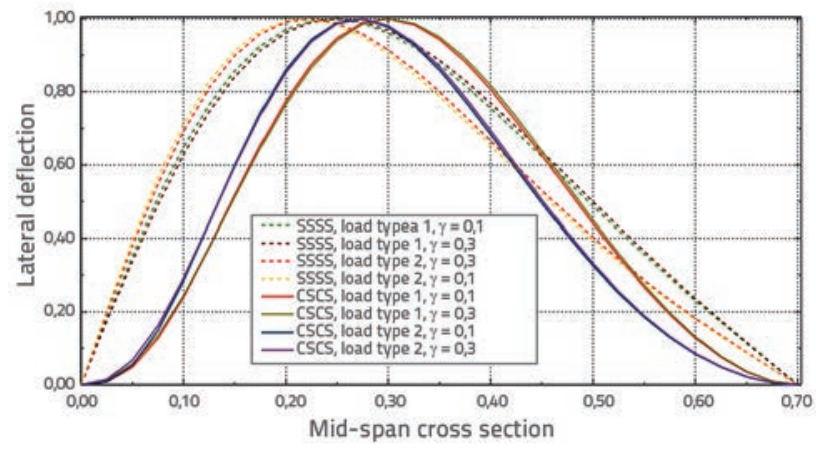

Figure 3. First buckling modes of plate $t_{w}=10 \mathrm{~mm}$; Mid-span cross section

\subsubsection{Analysis of results and conclusions}

Differences between the calculated buckling coefficients for plates $5 \mathrm{~mm}$ and $10 \mathrm{~mm}$ in thickness, with identical boundary conditions, load type and load length, are negligible (Table 1). This could have been expected since the critical load was calculated according to the theory of elastic stability. For this reason, further analysis of results (Table 2 and Figure 3) was focused on plates $10 \mathrm{~mm}$ in thickness.

Deviations of numerically calculated buckling coefficients from analytical results [8] are within acceptable limits (up to $0.76 \%$ for the type 1 load), which confirms accuracy of the numerical calculation procedure. The consistence of numerical and analytical results for the isolated plate is the real basis for the expected accuracy of the 3D numerical analysis, which is conducted in Section 2.3. Buckling coefficients calculated by the finite element method are lower than analytical values (Table 1), because of the limited number of terms in the interpolation functions.
The introduction of uniform shear stresses along web height in the analysis causes plate relaxation, i.e. an increase of critical buckling force up to $13.3 \%$ and $20.7 \%$, in the case of SSSS and CSCS boundary conditions, respectively (Table 1).

The well-known fact from literature $[2,4]$ that the load length affects the critical buckling force intensity is confirmed. A slight increase of critical force in the case of $\gamma=0.3$, in comparison with the case of $\gamma=0.1$, was registered. The above increase ranges between $4.16 \%$ and $5.35 \%$, and between $5.90 \%$ and $6.78 \%$, in the case of SSSS and CSCS boundary conditions, respectively (Table 1). Slight deviations of critical forces were confirmed through analysis of plates buckling modes for $\gamma=$ 0.3 and $\gamma=0.1$ (Table 2, Figure 3), where almost identical first buckling modes were registered.

Finally, after introduction of two clamped edges in the analysis (CSCS boundary conditions), an expected increase of the buckling coefficient was registered, compared to $k$, for the plate simply supported at all edges (SSSS boundary conditions). For the load types 1 and 2, the value of $k$ increased by about 1.9 and 2.1 times, respectively (Table 1). Thus the upper and lower limits of the buckling coefficient were defined, and they should include all intermediate values of $k$ in the case of elastically restrained edges at the web-flange junctions.

\subsection{D model}

It was confirmed in the previous Section that the introduction of an uniform shear stress component, as a separate plate, in the transverse I-girder stiffener zone significantly increases the critical force during the elastic stability analysis of web. The introduction of shear stresses at the web-flanges contact in the analysis would raise the $2 \mathrm{D}$ model to a higher level, through further approximation of stress function in the plate to the real stress notation in the girder web. This standpoint was investigated through a series of 3D numerical models of a thin-walled I-girder subjected to patch load (Figure 4).

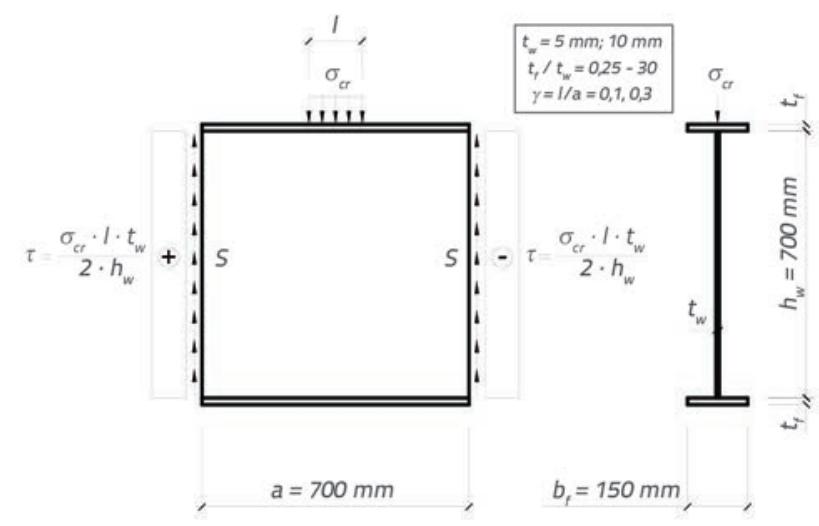

Figure 4. 3D model

In addition to general numerical-model parameters defined in Section 2.1, 3D models have the following properties: $\sigma_{c r}$ load is equilibrated with uniform shear $(\tau)$ in the zone of vertical 
Table 3. Tabulation of numerical analysis results

\begin{tabular}{|c|c|c|c|c|c|c|c|c|c|c|c|}
\hline \multicolumn{12}{|c|}{$\gamma=0.1$} \\
\hline \multicolumn{4}{|c|}{ 3D model } & & & \multicolumn{4}{|c|}{ 3D model } & & \\
\hline \multicolumn{2}{|c|}{$\mathrm{a}=\mathrm{h}_{\mathrm{w}}=$} & \multicolumn{2}{|c|}{$700 \mathrm{~mm}$} & & & \multicolumn{2}{|c|}{$\mathrm{a}=\mathrm{h}_{\mathrm{w}}=$} & \multicolumn{2}{|c|}{$700 \mathrm{~mm}$} & & \\
\hline & $t_{w}=$ & \multicolumn{2}{|c|}{$10 \mathrm{~mm}$} & & & \multicolumn{2}{|r|}{$t_{w}=$} & \multicolumn{2}{|l|}{$5 \mathrm{~mm}$} & & \\
\hline & $I=$ & \multicolumn{2}{|c|}{$=70 \mathrm{~mm}$} & & & \multicolumn{2}{|r|}{$I=$} & \multicolumn{2}{|c|}{$70 \mathrm{~mm}$} & & \\
\hline$\gamma=1$ & $/ a=$ & \multicolumn{2}{|l|}{0,1} & & & \multicolumn{2}{|c|}{$\gamma=1 / a=$} & \multicolumn{2}{|l|}{0,1} & & \\
\hline & $E=$ & \multicolumn{2}{|c|}{$10000 \mathrm{kN} / \mathrm{cm}^{2}$} & & & \multicolumn{2}{|r|}{$E=$} & \multicolumn{2}{|c|}{$10000 \mathrm{kN} / \mathrm{cm}^{2}$} & & \\
\hline & $v=$ & \multicolumn{2}{|c|}{0,3} & & & & $v=$ & 0,3 & & & \\
\hline$t_{f}[\mathrm{~mm}$ & & $t_{f} / t_{w}$ & $\mathrm{~F}_{\mathrm{cr}}[\mathrm{kN}]$ & $\sigma_{c r}\left[\mathrm{kN} / \mathrm{cm}^{2}\right]$ & $\mathrm{k}$ & $t_{f}[\mathrm{~mm}$ & & $t_{f} / t_{w}$ & $F_{c r}[k N]$ & $\sigma_{\mathrm{cr}}\left[\mathrm{kN} / \mathrm{cm}^{2}\right]$ & $\mathrm{k}$ \\
\hline 2,5 & & 0,25 & 436,27 & 62,32 & 33,79 & 1,25 & & 0,25 & 55,1 & 15,74 & 34,14 \\
\hline 5 & & 0,5 & 467,95 & 66,85 & 36,24 & 2,5 & & 0,5 & 58,958 & 16,85 & 36,53 \\
\hline 10 & & 1 & 561,22 & 80,17 & 43,47 & 5 & & 1 & 70,754 & 20,22 & 43,84 \\
\hline 20 & & 2 & 797,46 & 113,92 & 61,76 & 10 & & 2 & 101,07 & 28,8 & 62,62 \\
\hline 30 & & 3 & 950,78 & 135,83 & 73,64 & 15 & & 3 & 119,08 & 34,02 & 73,78 \\
\hline 40 & & 4 & 1030,5 & 147,21 & 79,81 & 20 & & 4 & 127,03 & 36,29 & 78,71 \\
\hline 50 & & 5 & 1080,7 & 154,39 & 83,70 & 25 & & 5 & 131,36 & 37,53 & 81,39 \\
\hline 70 & & 7 & 1154 & 164,86 & 89,38 & 35 & & 7 & 137,19 & 39,20 & 85,00 \\
\hline 100 & & 10 & 1248 & 178,29 & 96,66 & 50 & & 10 & 144,41 & 41,26 & 89,48 \\
\hline 300 & & 30 & 1511,1 & 215,87 & 117,03 & 150 & & 30 & 181,46 & 51,85 & 112,43 \\
\hline & late, & load typ & & & & & late, I & load typ & & & \\
\hline & Bou & ndary c & ditions & & & & Boun & ndary co & ditions & & \\
\hline$k=$ & SS & 5SS & CSCS & & & $k=$ & SS & & CSCS & & \\
\hline & 32 & 2,88 & 69,39 & & & & 32 & & 69,7 & & \\
\hline & & & & & & & & & & & \\
\hline 3D moc & & & & & & 3D moc & & & & & \\
\hline $\mathrm{a}=$ & $\mathrm{P}_{\mathrm{w}}=$ & $700 \mathrm{~m}$ & & & & $\mathrm{a}=$ & $h_{w}=$ & $700 \mathrm{~m}$ & & & \\
\hline & $t_{w}=$ & $10 \mathrm{~mm}$ & & & & & $t_{w}=$ & $5 \mathrm{~mm}$ & & & \\
\hline & $I=$ & $210 \mathrm{~m}$ & & & & & $I=$ & $210 \mathrm{~m}$ & & & \\
\hline$\gamma=1$ & $a=$ & 0,3 & & & & $\gamma=1$ & $/ a=$ & 0,3 & & & \\
\hline & $E=$ & 10000 & $\mathrm{~V} / \mathrm{cm}^{2}$ & & & & $E=$ & 10000 & $\mathrm{~N} / \mathrm{cm}^{2}$ & & \\
\hline & $v=$ & 0,3 & & & & & $v=$ & 0,3 & & & \\
\hline $\mathrm{t}_{\mathrm{f}}[\mathrm{mm}$ & & $t_{f} / t_{w}$ & $\mathrm{~F}_{\mathrm{cr}}[\mathrm{kN}]$ & $\sigma_{\mathrm{cr}}\left[\mathrm{kN} / \mathrm{cm}^{2}\right]$ & $\mathrm{k}$ & $t_{f}[\mathrm{~mm}$ & & $t_{f} / t_{w}$ & $\mathrm{~F}_{\mathrm{cr}}[\mathrm{kN}]$ & $\sigma_{c r}\left[\mathrm{kN} / \mathrm{cm}^{2}\right]$ & $\mathrm{k}$ \\
\hline 2,5 & & 0,25 & 471,99 & 22,48 & 12,19 & 1,25 & & 0,25 & 59,388 & 5,66 & 12,27 \\
\hline 5 & & 0,5 & 499,06 & 23,76 & 12,88 & 2,5 & & 0,5 & 62,751 & 5,98 & 12,96 \\
\hline 10 & & 1 & 593,29 & 28,25 & 15,32 & 5 & & 1 & 74,726 & 7,12 & 15,43 \\
\hline 20 & & 2 & 835,55 & 39,79 & 21,57 & 10 & & 2 & 105,92 & 10,09 & 21,88 \\
\hline 30 & & 3 & 992,59 & 47,27 & 25,63 & 15 & & 3 & 124,6 & 11,87 & 25,73 \\
\hline 40 & & 4 & 1071,6 & 51,03 & 27,67 & 20 & & 4 & 132,75 & 12,64 & 27,42 \\
\hline 50 & & 5 & 1119,1 & 53,29 & 28,89 & 25 & & 5 & 136,99 & 13,05 & 28,29 \\
\hline 70 & & 7 & 1186,4 & 56,50 & 30,63 & 35 & & 7 & 142,29 & 13,55 & 29,39 \\
\hline 100 & & 10 & 1273,1 & 60,62 & 32,87 & 50 & & 10 & 148,64 & 14,16 & 30,70 \\
\hline 300 & & 30 & 1516,2 & 72,20 & 39,14 & 150 & & 30 & 182,69 & 17,40 & 37,73 \\
\hline & late, I & load typ & & & & & late, I & load typ & & & \\
\hline & Bour & ndary co & ditions & & & & Boun & ndary co & ditions & & \\
\hline$k=$ & SS & SS & CSCS & & & $k=$ & SS & & CSCS & & \\
\hline & 11 & 1,7 & 24,51 & & & & 11, & & 24,6 & & \\
\hline
\end{tabular}


stiffeners; at lateral edges of the web, the node displacement perpendicular to the web plane is restrained (S), and thus transverse stiffeners of the I-girder are modelled; the node displacement perpendicular to the web plane is also restrained at one of the longitudinal edges of the upper and lower I-girder flanges, and thus the cross sectional rotation of girder is continuously restrained; reference surfaces of the web and flanges coincide with the midsurface of shell elements, i.e. the finite element mesh is identical in all 3D models, which differ from each other by shell thickness only (Figure 4); nodes on the flanges-web junction have a common rotation and displacement in three directions; load propagation through the loaded flange increases intensity of the buckling coefficient by increasing the load length on the isolated web, but this effect is not treated in the present analysis because of the adopted load modelling method described in Section 21; the flange to web thickness ratios of less than 1 and more than 5 are not realistic, and so they were treated from the theoretical point of view only, in order to identify appropriate regularities.

The results obtained by 3D numerical analysis of girder stability, and comparison with the $2 \mathrm{D}$ numerical analysis of web as an isolated plate (type 2 load), are presented in Tables 3-6. The stress notation in the girder was also analysed, particularly the distribution of stress at the flange-web contact (Tables 7-9). Stresses are labelled as follows: 512 shear stresses; 511 - normal stresses in horizontal direction; S22-normal stresses in vertical direction; and Smax and Smin - principal stresses. In the scope of the "eigenvalue buckling" analysis, stresses are calculated based on node displacement after the girder stability loss [7]. Stresses calculated in this way are useless for the analysis, which is why new numerical models with the "static, linear perturbation „ procedure were created. The new models differ from the existing ones only in the type of the analytical procedure. In all numerical tests, an arbitral intensity of patch load was applied rather than the critical load intensity. Thus, the relative stress intensity is shown in stress diagrams presented in Tables 7-9, and only the shape of the diagrams was analyzed.

\subsubsection{Analysis of results and conclusions}

Based on the results of numerical analyses (Tables 3 and 4), it can be concluded that buckling coefficients are approximately equal in the case of different web thicknesses $(10 \mathrm{~mm}$ and 5 $\mathrm{mm}$ ) for girders with the flange to web thickness ratio of up to 4 . However, deviation is significant for girders with $t_{f} / t_{w}$ $>4$. An undefined trend of the $k$ value increase for webs 10 $\mathrm{mm}$ in thickness, compared to webs $5 \mathrm{~mm}$ in thickness, can be observed. The ratio $t_{f} / t_{w}$ is extended to an unrealistic

Table 4. Graphical presentation of numerical analysis results

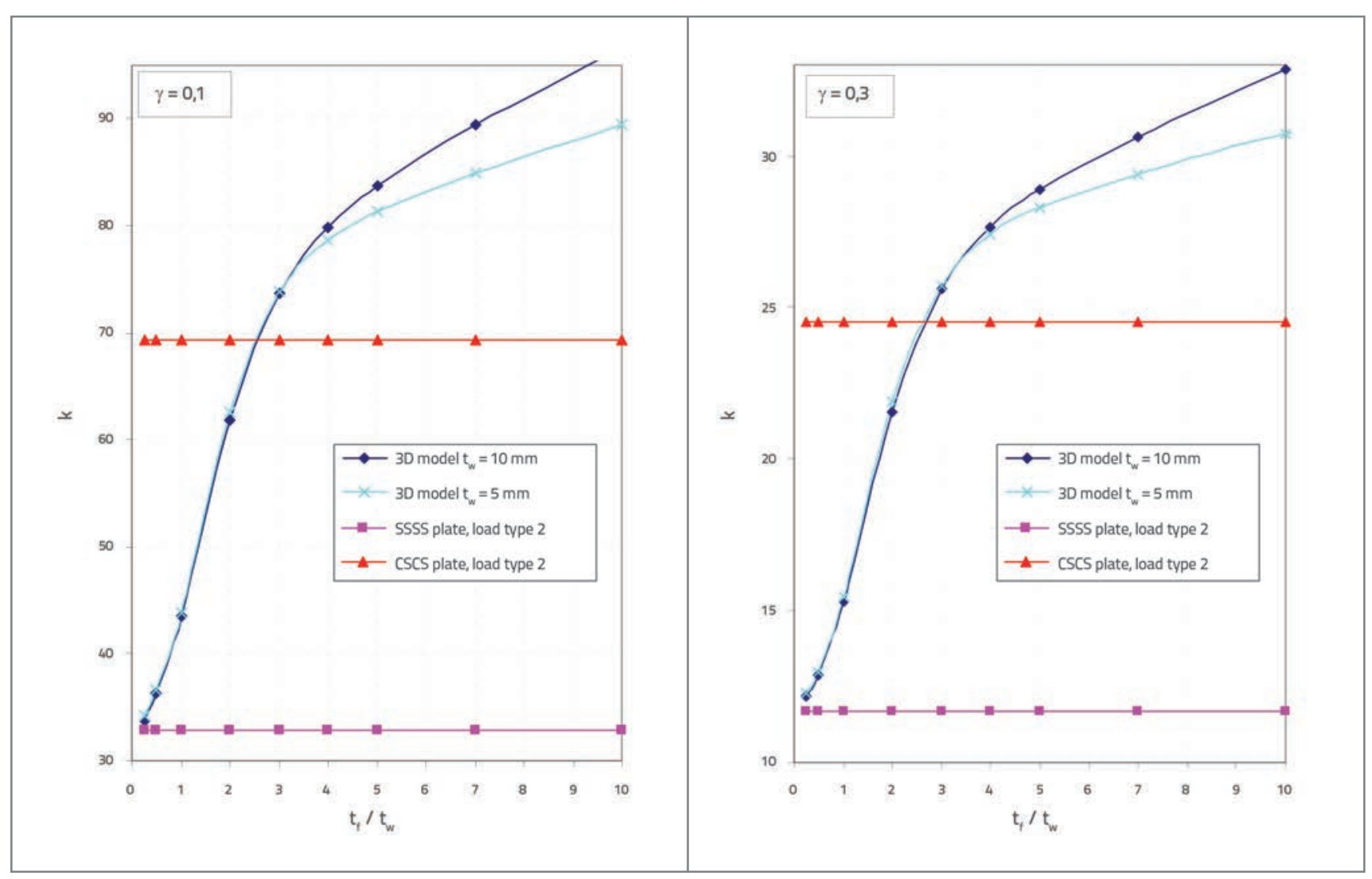


Table 5. First buckling modes of 3D model, $t_{w}=10 \mathrm{~mm}, \gamma=0,1$

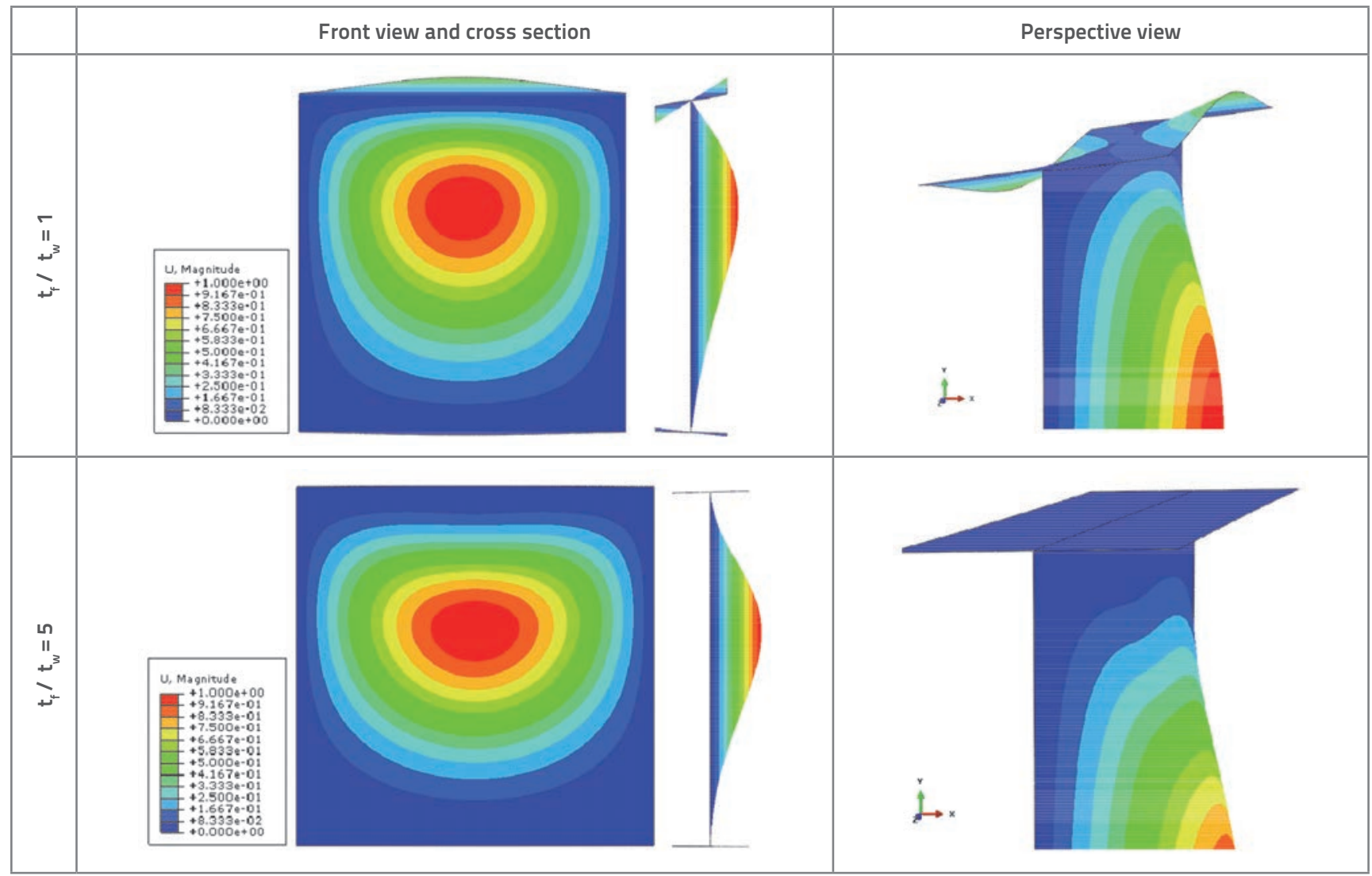

Table 6. First buckling modes $t_{w}=10 \mathrm{~mm}-$ mid-span cross section

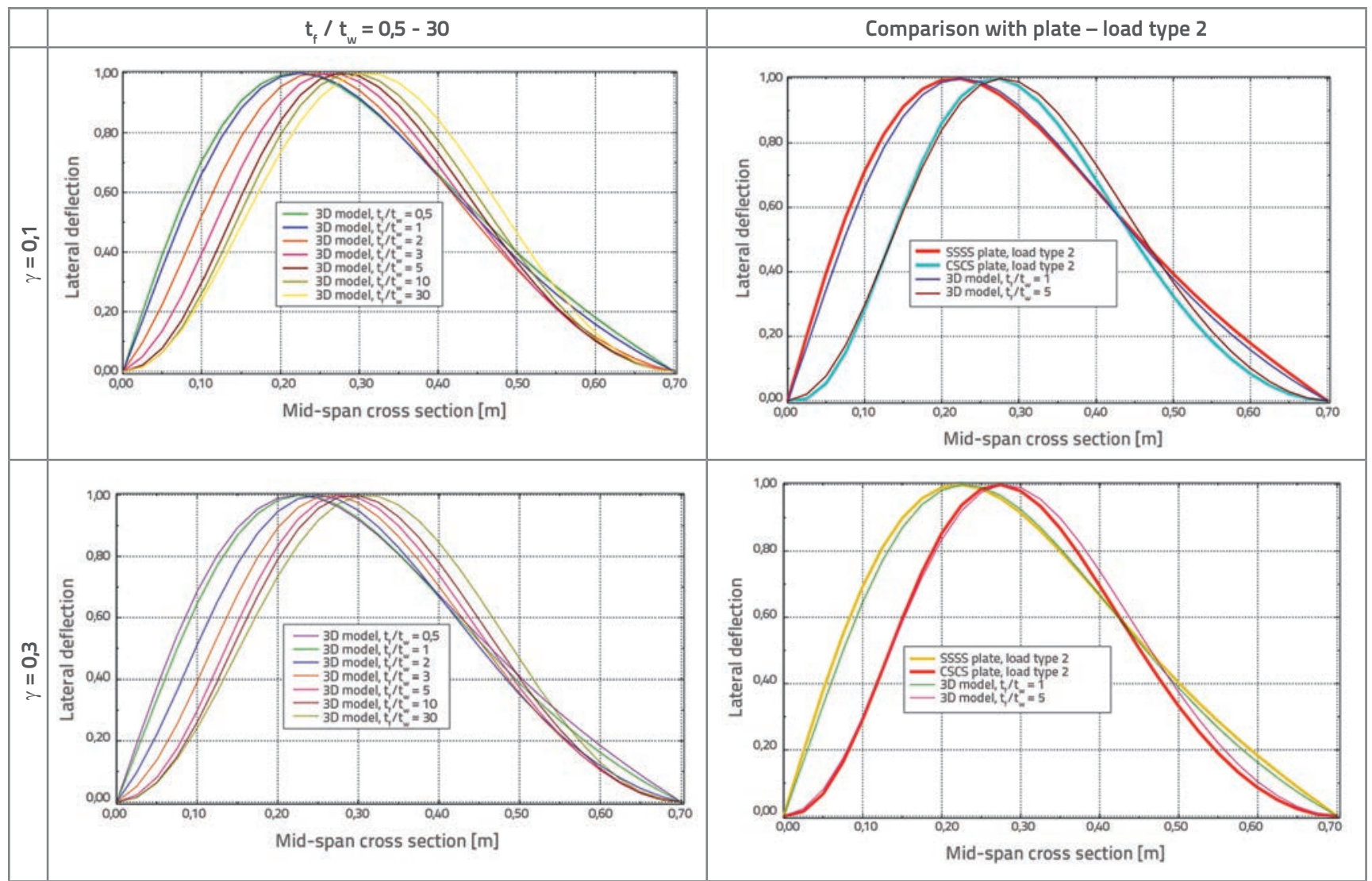


Table 7. Shear stresses (S12) at the junction $\left(t_{w}=10 \mathrm{~mm}\right)$

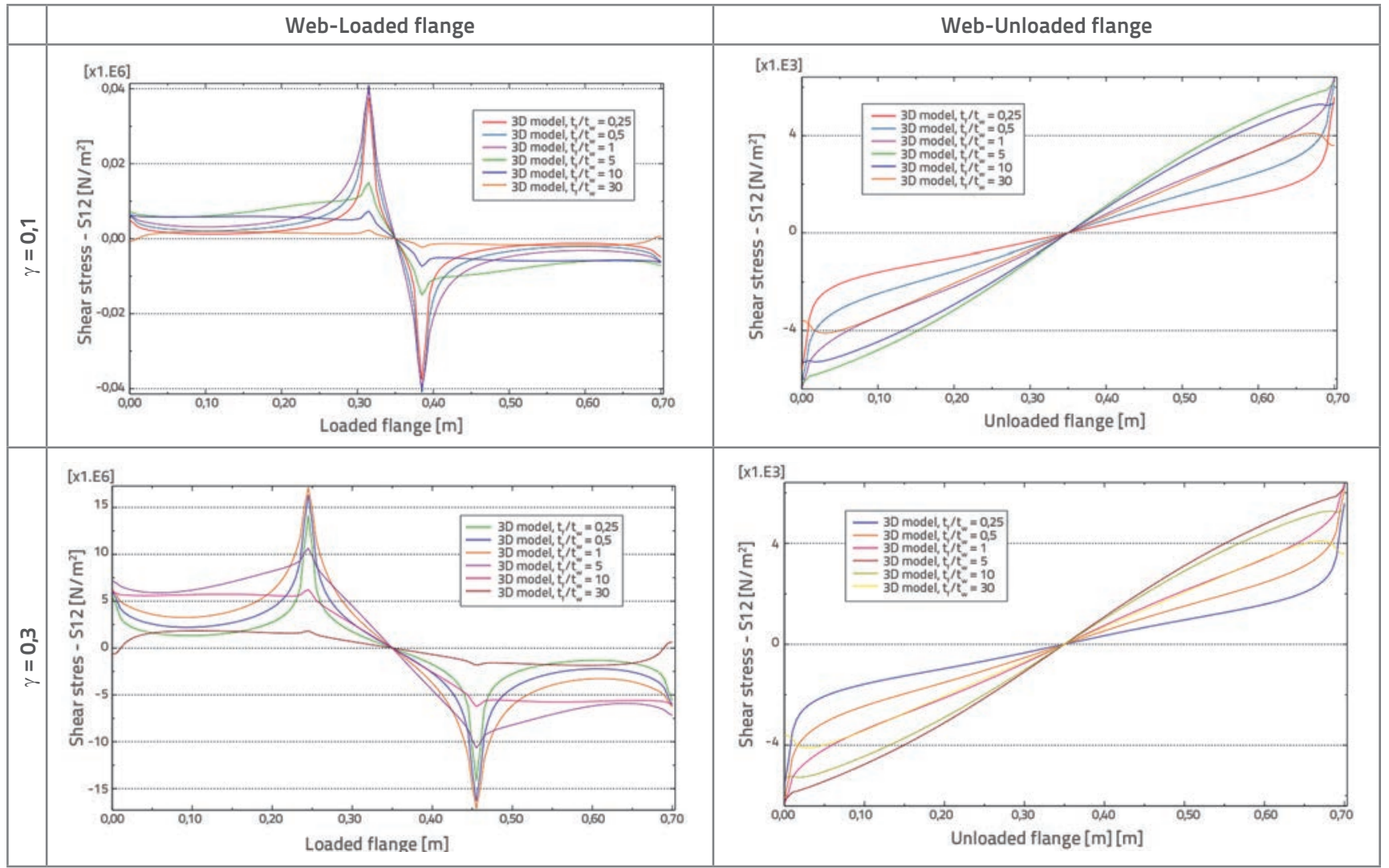

Table 8. Normal stresses on the web $\left(t_{w}=10 \mathrm{~mm}\right)$, loaded flange junction

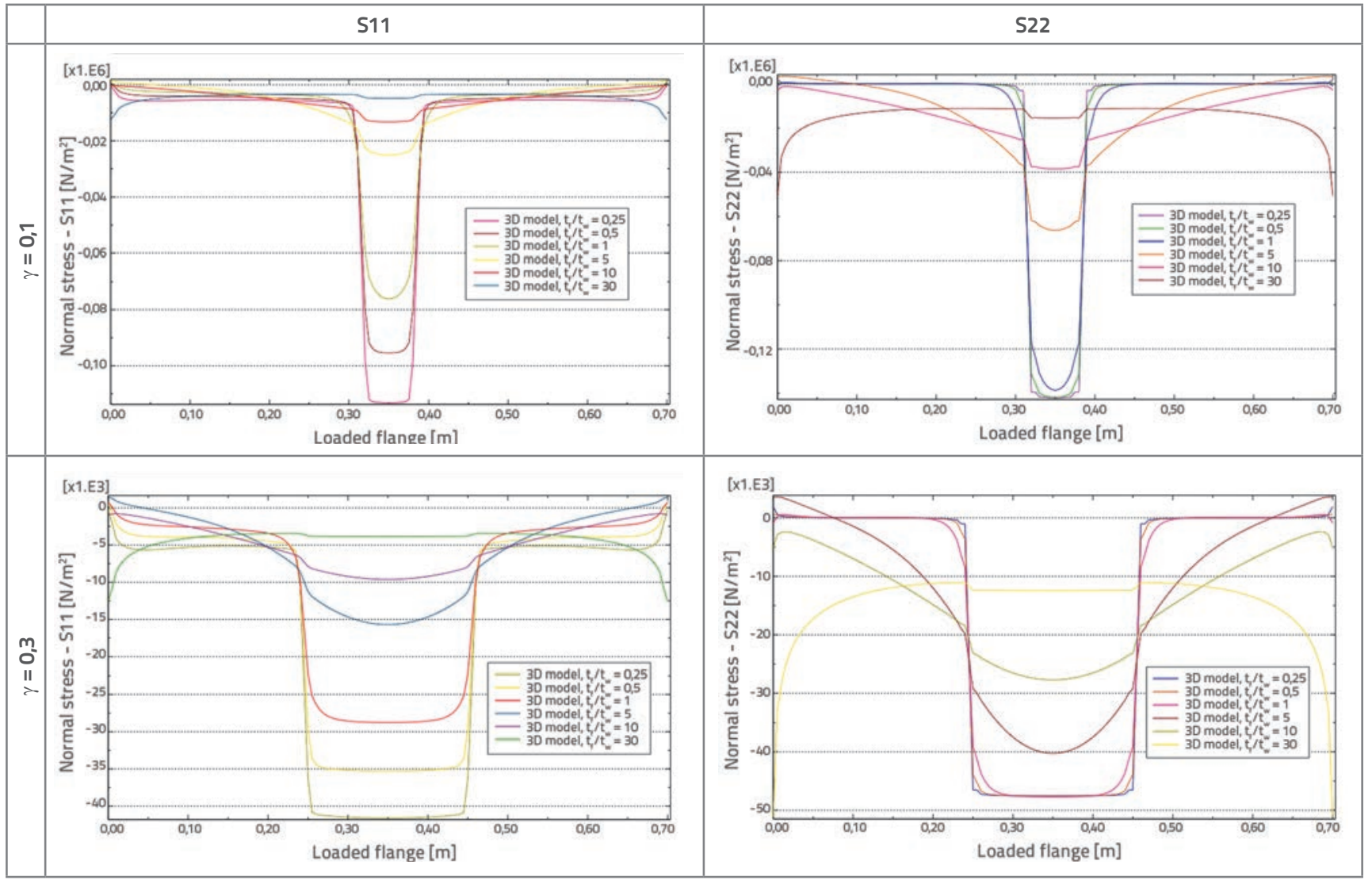


Table 9. Principal stresses on the web $\left(t_{w}=10 \mathrm{~mm}\right)$, loaded flange junction

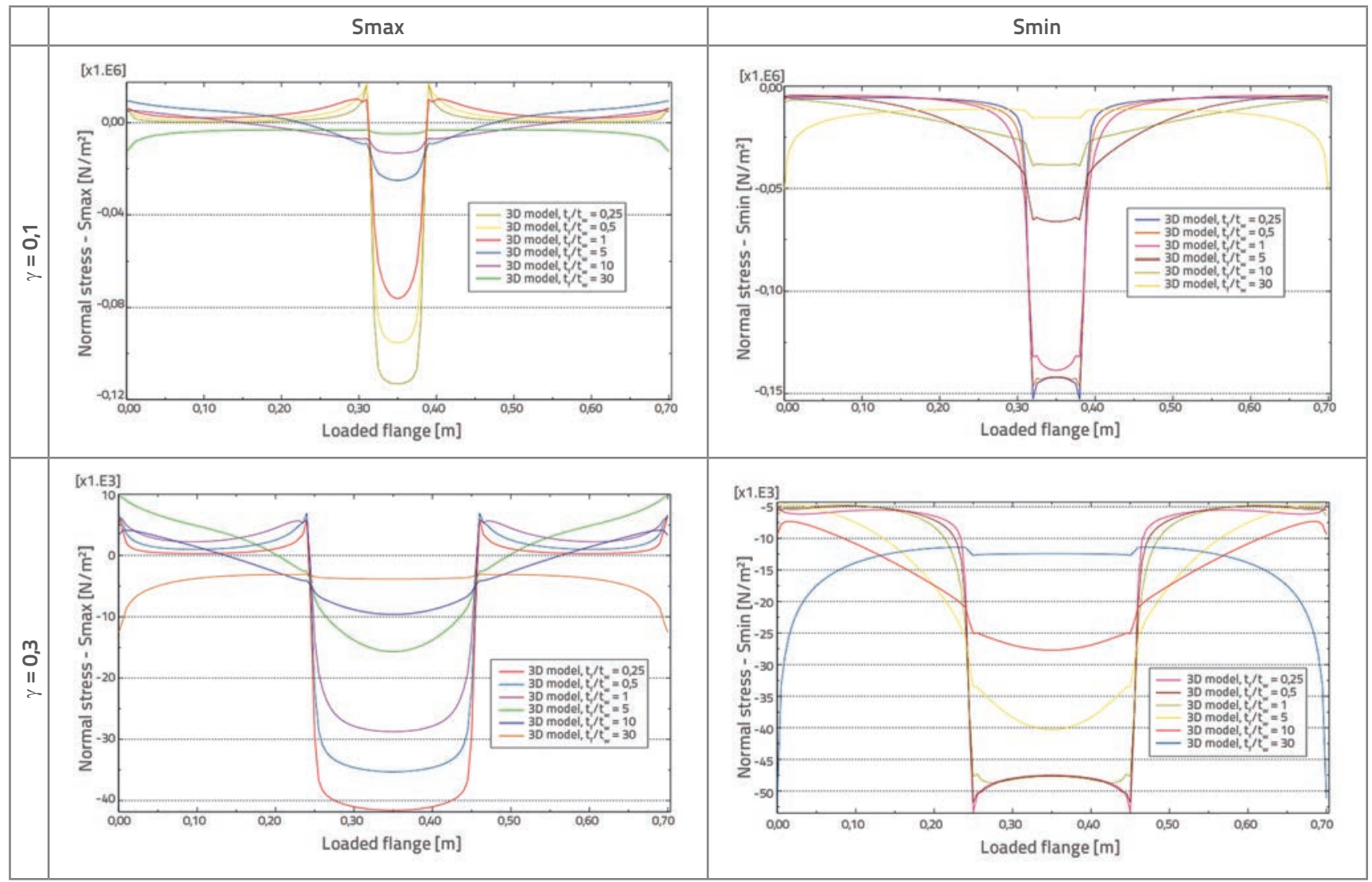

range ( $1>t_{f} / t_{w}>5$ ) because of the perceived regularities in the case of other 3D models, which will be the subject of future papers.

The buckling coefficient $k$ for the isolated plate with SSSS boundary conditions (type 2 load) is the lower limit of $k$ for l-girder. However, the value of $k$ for the plate with CSCS boundary conditions is not an upper limit of $k$ for the I-girder, as indicated in Section 2.2.1. In fact, for the ratios of $t_{f} / t_{w}$ $>3$ numerical values of the coefficient $k$ significantly exceed the $k$ value for the plate with a pair of simply supported and clamped edges. Thus it has been theoretically proven that the buckling coefficient intensity is influenced not only by the elastic restraint of web, but also by other factors, which are due to the introduction of flanges into the analysis. Shear at the flange-web junction, bending, axial and torsional stiffness of loaded flange, and load propagation through the loaded flange, are the accompanying effects of the flange presence in the stability analysis of thin-walled I-girders subjected to patch load. Although the conducted numerical analyses do not enable identification of individual influence of the mentioned effects on the critical load level, we still can make some appropriate conclusions, as presented below.

Tables 5 and 6 show how the buckled web "belly" moves down (toward the unloaded flange) with an increase of the $t_{f} / t_{w}$ ratio, i.e. with an increase of the restraint level at the web-flange junction. This graphically shows the influence of elastic restraint at the web-flange junction on the intensity of buckling coefficient.

The influence of the loaded-flange torsional stiffness on the critical load intensity can be seen through the perspective view of first buckling modes (Table 5). In the case of thinner flanges, the twisting of the loaded flange can be observed, which does not happen in case of thicker flanges as they are torsionally stiffer.

The influence of the loaded-flange bending stiffness on the critical load intensity can be observed based on the diagrams of normal stresses in vertical direction (S22) (Table 8). With an increase in flange thickness, the engaged width of the web increases, the web relaxation occurs, i.e. the critical load (buckling coefficient) increases.

The influence of the loaded-flange axial stiffness on the critical load intensity can be seen through shear-stress diagrams for the flange-web junction (Table 7). In the case of thinner flanges, the shear stress distribution has an irregular shape with clear peaks in the patch load end zone. Thus a narrow zone of the loaded flange is axially engaged and therefore the influence of the loaded-flange axial stiffness on the critical load intensity is lower. In the case of thicker flanges, the shear stress distribution has a shape of a transverse force diagram for beam girder. Thus the complete flange is axially engaged and therefore the influence of the loaded-flange axial stiffness on the critical load intensity is higher. 
Based on the analysis of shape of the shear stress diagram at the web-loaded flange junction as a function of the flange thickness (Table 7), which is exposed in the preceding paragraph, it can be concluded that during the stability analysis of the web as an isolated plate, the shear should be modelled with a pair of concentrated forces in the patch load end zone in the case of thinner flanges, while in the case of thicker flanges, the shear has a shape of the transverse force diagram according to the traditional beam girder theory.

Shear stress diagrams at the web-unloaded flange junction (Table 7) have a constant linear distribution along the junction, regardless of the flange thickness, for the analyzed I-girder geometry $(\varnothing=a / b=1)$.

In the web zone below the patch load, there is an expected concentration of compressive stresses in vertical direction (S22) in the case of girders with thinner flanges. Slightly lower concentration of compressive stresses in horizontal direction (S11) is also observed, as a result of local deformation of girder in the zone of patch loading. With an increase in flange thickness (stiffness), the stress concentration is reduced, i.e. a larger web width is engaged (Table 8).

In the case of the thinner flanges, principal tensile stresses occur at the web-loaded flange junction in the patch load end zones, which extend towards the edges of the girder (Table 9). The appearance of normal tensile stresses in the web zone just below the patch load was observed in the experimental research conducted at the Faculty of Civil Engineering in Podgorica [11, 12]. The tensile stresses are the result of concentration of shear stresses, which were previously analyzed. In the case of thicker flanges, principal tensile stresses occur in the girder edge zones at the web-loaded flange junction (Table 9).

Finally, an increase of the critical force intensity was observed in the case of load distributed along the length $/=210 \mathrm{~mm}$ $(\gamma=0.3)$, compared to the case $/=70 \mathrm{~mm}(\gamma=0.1)$, which is similar to the case of an isolated plate. The rate of increase constantly diminishes with an increase of the $t_{f} / t_{w}$ ratio. For $t_{f} / t_{w}=0.25$ the rate of increase is $8.19 \%$ for $t_{w}=10 \mathrm{~mm}(7.78$ $\%$ for $\left.t_{w}=5 \mathrm{~mm}\right)$, whereas for $t_{f} / t_{w}=30$ the rate of increase is $0.34 \%$ for $t_{w}=10 \mathrm{~mm}\left(0.68 \%\right.$ for $\left.t_{w}=5 \mathrm{~mm}\right)$.

\section{Conclusions}

The numerical analysis conducted in this study confirmed a significant impact of flanges and real distribution of shear stresses in the zone of vertical stiffeners on the intensity of buckling coefficient of thin-walled I-girders subjected to patch load. The influence of flanges is expressed through a series of effects, the most notable ones being: elastic restraint and shear at the (un)loaded flange-web junctions; bending, axial and torsional stiffness of the loaded flange; and load propagation through the loaded flange. The last effect is not treated in the scope of this analysis. Although individual influence of the said effects on the critical load level can not be differentiated, it can nevertheless be concluded that the effects of elastic restraint and shear at the flange-web junctions are dominant.

Future research should focus on the formation of $2 \mathrm{D}$ models with shear at the flange-web junction as a function of flange thickness. This would allow definition of the individual influence of shear on the intensity of critical load.

\section{REFERENCES}

[1] EN1993-1-5. Eurocode 3. Design of steel structures - Part 1-5: Plated structural elements, CEN, 2006.

[2] Mijušković, O.: Analiza stabilnosti pravougaonih ploča koriščenjem tačne funkcije napona, Doktorska disertacija, Građevinski fakultet, Beograd, 2008.

[3] Lagerqvist, O., Johansson, B.: Resistance of I-girders to Concentrated Loads, Journal of Constructional Steel Research, Vol. 39, No. 2, pp. 87-119, 1996.

[4] Ren, T., Tong, G.S.: Elastic buckling of web plates in I-girders under patch and wheel loading, Engineering Structures, Vol. 27, pp. 1528-1536, 2005.

[5] Maiorena, E., Pellegrino, C., Modena, C.: Linear buckling analysis of unstiffened plates subjected to both patch and bending moment, Engineering Structures, Vol. 30, pp. 37313728, 2008.

[6] Mezghanni, O., Averseng, J., Bouchair, A., Smaoui, H.: Behavior of beam web panel under opposite patch loading, Journal of Constructional Steel Research, Vol. 83, pp. 51-61, 2013.
[7] ABAQUS 6.11 Version, Manuals, USA: Abaqus Inc. 2005.

[8] Mijušković, O., Ćorić, B.: Patch loading - analytical approach to critical load determination, Gradevinar 65 (2013) 1, pp. 1-10.

[9] Liu, Y.G.: Buckling of Plates under Non-Uniform Stresses, with Particular Emphasis on Shear, PhD Thesis, Imperial College, London, 2006.

[10] Timošenko, S.: Teorija elastične stabilnosti, "Naučna knjiga", Beograd, 1952.

[11] Aleksić, S., Rogač, M., Lučić, D.: Analysis of locally loaded steel plate girders-Model for patch load resistance, Journal of Constructional Steel Research, Vol. 89, pp. 153-164, 2013.

[12] Aleksić, S., Lučić, D., Šćepanović, B.: Eksperimental research Centro 2009, Materijali i konstrukcije 52 (2009) No. 3-4, pp. 4761. 